\title{
Support Networks for Community-Based Tourism in Rural Costa Rica ${ }^{\#}$
}

\author{
Bernardo Trejos ${ }^{1}$, Lan-Hung Nora Chiang ${ }^{2, *}$ and Wen-Chi Huang ${ }^{3}$
}

\begin{abstract}
${ }^{I}$ Department of Tropical Agriculture and International Cooperation, National Pingtung University of Science and Technology, Taiwan; ${ }^{2}$ Department of Geography, National Taiwan University, Taiwan and ${ }^{3}$ Department of Agribusiness Management, National Pingtung University of Science and Technology, Taiwan
\end{abstract}

\begin{abstract}
Tourism has been promoted as a rural development strategy in many countries. In Costa Rica, this has been done through a network of private and public organizations that support community-based tourism in rural areas. The objective of this research is to analyze how embedding grassroots organizations (GROs) in support networks may overcome some of the limitations encountered in the practice of rural tourism. Network theory is used to explain the rationale behind the development and implementation of these networks. Through a case study of two tourism-specific grassroots support organizations, it was found that support networks directly tackle some of the common problems faced by rural inhabitants in the practice of tourism, which are lack of essential skills, high development costs, and the dominance of mass tourism operators. Although the supported GROs are receiving tourists and revenues, support networks have not solved the problems of low employment and income.
\end{abstract}

Key Words: Community-based tourism, rural tourism, networks, NGOs, Costa Rica.

\section{INTRODUCTION}

Tourism has been promoted as a development strategy in many countries, particularly in peripheral rural areas where traditional agrarian industries have been losing ground [1-4]. However, past research has identified several problems associated with the development of tourism in these areas, as can be seen in Table 1. Although tourism in rural areas utilizes idle human resources present in households, traditional agriculture in general is more efficient with regard to generating income [1]. Tourism is not a universal panacea, since the economy of rural areas is best served when rural tourism is integrated into wider development plans [4].

In the absence of formalized planning and intervention, the possibilities for a community to benefit from tourism are limited [5]. On the other hand, external alliances may help community-based projects strengthen skills and political influences, as well as develop internationally accepted standards and effective marketing [6]. Based on this assumption, we examined whether ties between community-based tourism businesses and external support networks may help overcome some of the limitations encountered in the practice of tourism in rural areas. In the next section, we will explain what we mean by community-based projects.

\section{Community-Based Tourism}

The most widely accepted definition for communitybased tourism (CBT) states that a high degree of control and

\footnotetext{
*Address correspondence to this author at the Department of Geography, National Taiwan University, Taiwan; E-mail: nora@ntu.edu.tw

\#This research was made possible by grants from the Taiwan Scholarship program and the National Pingtung University of Science and Technology. Institutional support also came from the Program of Social Study of Science, Technology and the Environment, Center for Geophysical Research (CIGEFI), University of Costa Rica. Special gratitude is expressed towards Marielena Moncada and Ana Luisa Trejos, who made valuable comments on the manuscript.
}

a significant proportion of the benefits must be in the hands of members of local communities [7-11]. A high level of community integration may lead to greater socioeconomic benefits from tourism for a majority of residents. Community integration has been defined in terms of decisionmaking power structures and processes, local control or ownership, type and distribution of employment, and the number of local people employed in the local tourism sector [8].

Table 1. Problems Associated with Rural Tourism

\begin{tabular}{|c|c|}
\hline Problem & Ref. \\
\hline \hline High development costs & {$[2]$} \\
\hline Lack of essential skills & {$[2]$} \\
\hline Dominance of mass tourism operators & {$[2]$} \\
\hline Low percentage of local inhabitants employed in tourism & {$[5]$} \\
\hline Low demand & {$[2]$} \\
\hline Financial returns that are not up to the expectations of the \\
people involved & {$[1]$} \\
\hline
\end{tabular}

There are however other definitions for CBT. For some researchers, it involves joint decision-making among a group of autonomous stakeholders in order to plan tourism development $[12,13]$. For others, it entails forming cooperative groups or community-based organizations [3, 14]. It may also be viewed as a symbiotic relationship where the tourist is not given central priority, but instead becomes an equal part in relation to brokers and locals [15]. 
While there is much support for CBT projects, it is difficult to find successful cases in practice, if we define success as a high level of control over tourism development and an equitable share in the benefits from tourism [7]. There are many factors that have been shown to affect CBT development, such as class, gender and patronage inequalities [16, 17]. Past research has found that power relations are endemic features of emerging CBT settings [13], which result in the domination of community-based projects by local elites who monopolize the benefits of tourism [17].

Policymakers may want to benchmark CBT with other policy options, since in terms of regional planning, other forms of tourism may also contribute significantly to socioeconomic development [18]. Past research has shown that the mode of participation, ranging from autonomous enterprises to pure salary employment, is less decisive for local income generation than the existence of natural attractions, the degree of tourism specialization, and the level of organization [19]. Internal collaboration, external partnerships, effective leadership, and secure access to locations are other factors that have been associated with the generation of equitable distribution of surplus revenue from tourism [20]. The following section will concentrate on one of these factors, i.e., the role of external partnerships.

\section{Support Networks}

Complex networks of actors are found at the local and global arenas, as well as in the public and private sectors of society. These networks include nongovernmental organizations (NGOs), communities, state agencies, intergovernmental organizations, private companies and international financial institutions [21]. According to Roberts, Roberts, and Fröhling [22], transnational networks of NGOs connect the spatially extensive international NGO sector to projects undertaken by grassroots NGOs. Although the term 'network' currently dominates development discourses about the relationships between organizations, there has been little research on such networks [23].

NGOs may play a significant role in addressing tourism development issues, since they have the capacity to assist in revenue generation and community-based development [24]. During the last decades, two types of NGOs have proliferated in Asia, Africa and Latin America, referred to as grassroots organizations (GROs) and grassroots support organizations (GRSOs). GROs are local-based membership groups that work to improve or develop their own communities, while GRSOs are intermediary organizations that work with and channel financial support to GROs. Unlike GROs, which may earn profits, GRSOs are nonprofit-oriented, although some carry out profit-oriented support activities [25].

Thus far, there is no research on how GRSOs may help develop tourism activities in rural areas. They may however have the potential to connect geographically isolated and under-resourced rural communities to organizations with financial capital, skills training and marketing abilities in the area of tourism development. Therefore, the objective of this research is to analyze how embedding these GROs in support networks may overcome some of the limitations faced in the practice of rural tourism (see Table 1). This objective will be met by analyzing the role that support organizations have played in the development of CBT projects in rural Costa Rica.

\section{COMMUNITY-BASED TOURISM IN COSTA RICA}

\section{Costa Rica's Tourism Policy}

Starting in the 1950s, large landowners and landless farmers extended agricultural lands into the peripheral areas of Costa Rica [26]. In response, the country has developed a park system in which 25 percent of all land falls into some kind of protection. This is considerable if compared to the other Central American countries [27, 28]. Despite insufficient funding, the public park system constitutes the base of a tourism industry that has relied on the country's natural diversity of flora, fauna and landscape [28].

Costa Rica has become a world-renowned destination for ecotourists. Its tourism industry has been based on smallscale, locally-owned accommodation and service businesses. However, in the 1990s, the government's avoidance of largescale developments began to fade. Numerous contracts were signed with international consortia for mass tourism developments that offered natural attractions and claimed proper environmental management [28]. Costa Rica's tourism sector has adopted 'eco' and 'green' labeling practices, but the value of such labels is questionable. The Costa Rica Tourism Board (Instituto Costarricense de Turismo, ICT) has called for an increase of environmentally sensitive tourism, but resists government attempts to regulate such development or to increase returns from tourism to nature conservation [29].

\section{CBT Policy in Costa Rica}

CBT has been promoted as a response to the mainstream tourism policy in Costa Rica. A difference must be made between CBT and Community-Based Rural Tourism (CBRT). While CBT is an academic concept, CBRT refers to a specific policy developed in Costa Rica, but that has already started to be replicated in other Central-American countries. The main characteristic of the CBRT policy is the presence of GRSOs that work specifically in the tourism sector. The two most emblematic of tourism-related GRSOs are the Costa Rican Association of Community-Based Rural Tourism (Asociación Costarricense de Turismo Rural Comunitario, ACTUAR) and the Cooperative Consortium -National Ecotourism Network (Consorcio Cooperativo Red Ecoturística Nacional, COOPRENA). ACTUAR and COOPRENA have a membership of 23 and 13 GROs respectively.

There are many other tourism businesses in rural areas that are not part of the CBRT policy, most of which are small-scale and locally owned [28]. In 2002, a study done by ICT included a total of 345 rural tourism businesses, and found that they offer a wide range of complementary services, e.g., lodging, food and drinks, organic farms, fishing, horse rides, camping areas, and various tours [30]. The findings of this research cannot be generalized to all rural tourism in Costa Rica, since the projects studied do not constitute a representative sample of rural tourism in Costa Rica. Compared to Costa Rica's rural tourism sector in general, CBRT has received considerable international support, which makes it an interesting case study. 
CBT has been promoted in Costa Rica primarily by a wide array of non-state organizations. Its most constant supporters have been the Small Grants Programme (SGP) (implemented by the United Nations Development Programme, UNDP), and two Costa Rican-based NGOs: Fundecooperación and ACEPESA. Fundecooperación was founded to administer the funds from the Bilateral Agreement on Sustainable Development between Costa Rica and the Netherlands. ACEPESA, the Central American Association for the Economy, Health and the Environment (Asociación Centroamericana para la Economía, la Salud y el Ambiente) has executed various projects for the support of small tourism businesses. More recently, there has been considerable support from the Rainforest Alliance and the Inter-American Development Bank (IADB).

International financial assistance for CBT has been channeled through complex networks of organizations linked to community-based projects. In order to receive support, most funding agencies require that a formal association be registered for each community-based enterprise. This does not mean that all members of a community have to be in these associations. However, most funding agencies support projects related to GROs, instead of individual persons from rural areas.

Public institutions have had a straggling but nonetheless crucial role in the development of CBT projects. The National Technical Education Institute (Instituto Nacional de Aprendizaje, INA) has given constant support to the subsector since the first projects started. More recently, ICT has started to support CBT projects through marketing efforts and evaluation of quality standards. ICT has implemented its tourism policy along three main tourism segments: ecotourism, adventure and "sun and sand". However, it has also tried to diversify tourism activities into other niches like rural, community-based, health and convention tourism [31]. In recent years there has been growing support from ICT for CBRT. For example, during the last CBRT fair, ICT was a major sponsor.

According to Guereña [32], the CBRT sector faces several limitations such as weak financial capacity and qualification in tourism and business aspects. As in many rural areas, they have deficiencies in infrastructure for transport, communication and basic services, which presents a comparative disadvantage.

Although ACTUAR and COOPRENA have different historical backgrounds, they perform in a similar way. They are GRSOs that have several member GROs, and have ties to international organizations, other NGOs, national and foreign state agencies, as well as travel agencies and tourists. Some of these organizations have had a long term role in the CBRT network. Other organizations have had a more transitory one, which may have involved only a single-moment donation or support activity. In this section, we have mentioned the organizations that have had a more stable role in the development of CBRT. However, it is beyond the scope of this paper to mention the totality of the organizations that have, in one way or another, supported CBT in Costa Rica. Readers may be interested in the partial lists found in UNDP [33] and Solano [34].

\section{COOPRENA}

COOPRENA's history is related to the search for economic alternatives at the heart of the Self-Managed Cooperative Movement. In November 1992, some leading members of the Permanent Commission of Self-managed Cooperatives (Comisión Permanente de Cooperativas de Autogestión, CPCA) received a warning from the Institute of Agrarian Development (IDA, the state institution that granted these cooperatives their land) stating that if they did not develop sustainable productive activities, they would be dissolved and their land would be divided [35]. The cooperatives under this system have a social property regime of indivisible character [36]. These leaders organized a tour during which they visited 8 cooperatives and conducted meetings. Delegates from each cooperative were chosen and recruited to continue the tour. When they reached the last cooperative, they celebrated the foundational assembly of the organization. In a later session, they changed the name to COOPRENA [35]. In 1994, the organization took the legal figure of consortium [34]. In 2007, the Consortium was integrated by 17 organizations, most of which were agrarian cooperatives.

COOPRENA has received funds from the Costa RicaCanada Debt Conversion Fund, Fundecooperación, the Swedish Cooperation Center, the National Cooperative Promotion Institute (Instituto Nacional de Fomento Cooperativo, INFOCOOP) [34], and more recently, IADB.

\section{ACTUAR}

ACTUAR's history is related to Integrated Development and Conservation Projects. The Global Environment Facility established the Small Grants Programme in 1992, the year of the Rio Earth Summit. ACTUAR was formed by a group of community organizations that had already received support from the SGP [37].

The SGP started financing CBRT projects in 1995 as a tool for local development and environmental conservation [38]. Financial support for tourism activities was not a result of formalized planning, but rather due to suggestions of rural groups that had little possibilities for generating income.

In 2001, the first Ecotourism Conference, a nationwide evaluation of the SGP, took place. There, they realized that there were already 20 groups throughout the country that were implementing CBRT, but were not getting the results they expected. Donations were going almost completely to infrastructure, but promotion was not being addressed. Although the local groups had similar activities and motivations, they did not know about each other. This is when the SGP started working on getting the groups to know each other and bringing training to the groups. ACTUAR started working as an informal umbrella organization. Its board of directors, chosen from the GROs that belonged to it, met about every 3 months. In December 2002, ACTUAR organized a General Assembly for the formalization of the association. With incipient resources, a management board was selected. In 2003, ACTUAR opened its offices in San José, the capital of Costa Rica. In 2007, ACTUAR had a membership of 24 GROs with tourism projects. The external funding for ACTUAR has come primarily from the SGP and IADB. 
Most of ACTUAR's members are peasant and fishermen organizations that have limited possibilities of developing income-generating activities. Others are environmental associations that develop tourism, so that they can fund environmental activities (e.g., environmental education). Some are women's groups or indigenous organizations integrated by people that live in Government-created indigenous reserves.

\section{THEORY AND METHODOLOGY}

This research analyzes the CBRT policy from the perspective of Granovetter's network theory. This theory stresses that weak ties are vital for an individual's integration into modern society [39]. The strength of a tie is defined in terms of the amount of time, emotional intensity, mutual confiding and reciprocal services that characterize each tie [40]. Individuals with few weak ties are deprived of information from distant parts of the social system, and confined to locally available information and views. Social systems that lack weak ties are fragmented and incoherent. New ideas spread slowly and groups which are separated by ethnicity, geography and other characteristics will have difficulty reaching a modus vivendi [39]. Weak ties are more likely to play the role of transmitting unique information across otherwise largely disconnected segments of social networks [41]. From a strategic point of view, an individual with many weak ties to other groups can turn diverse and relevant information to its advantage [42]. From this perspective, the hypothesis may be raised that GRSOs link GROs to other parts of the social system in ways that would otherwise be unconnected.

When using a network as an analytical tool, the question of where it starts and ends is crucial, since a network does not have distinct boundaries [43]. Although there were various tourism-related GRSOs in Costa Rica, only two had nationwide coverage. This research focused on the direct linkages around these two GRSOs and six of their member GROs.

Since our interest was on the ways in which networks may help develop CBT businesses, we chose to do a qualitative study. We studied networks not as static entities, but as part of an ongoing and emergent process [23]. We did not choose to do a quantitative mapping of the CBRT support network, since the study of the structure of relations may generate bias towards more stable relations, and sacrifice the understanding of the content of the relations. According to Rutten [44], it is the content of network relations that should be examined rather than their structure.

From 2005 to 2007, In-depth interviews were carried out and recorded with key informants from organizations related to CBRT (See Table 2). Informants from 6 GROs were included in the study, so as to cover diverse types of organizations and geographical locations. As unsuccessful cases abound in the literature, these GROs were chosen because there was an informal consensus among interviewees that these were successful cases. No measurement of success was done for this study.

Questions consisted of open and closed questions about the social linkages between organizations. Some of the interviews were followed by e-mail or telephone requests of additional information when needed. Interviews were triangu- lated and contrasted with published and unpublished documents, as well as with observation in the GRO-owned tourism businesses and in the communities where they were located.

Table 2. Source of Key Informants for this Research

\begin{tabular}{|c|c|}
\hline Name of Organization & Type \\
\hline ACTUAR & GRSO \\
\hline COOPRENA & GRSO \\
\hline Albergue la Amistad ${ }^{\mathrm{a}}$ & GRO (Women's) \\
\hline Nacientes Palmichal $^{\mathrm{a}}$ & GRO (Environmental) \\
\hline Stibrawpa $a^{\mathrm{a}}$ & GRO (Indigenous) \\
\hline Albergue Heliconias ${ }^{\mathrm{b}}$ & GRO (Farmer's association) \\
\hline Coopesilencio $^{\mathrm{b}}$ & GRO (Self-managed Cooperative) \\
\hline Coopeuvita $^{\mathrm{b}}$ & GRO (Cooperative) \\
\hline Costa Rican Tourism Board & State institution \\
\hline $\begin{array}{l}\text { National Technical Education } \\
\text { Institution }\end{array}$ & State institution \\
\hline ACEPESA & Local NGO \\
\hline Rainforest Alliance & International NGO \\
\hline Fundecooperacion & Bilateral NGO \\
\hline UNDP & Intergovernmental organization \\
\hline
\end{tabular}

The main themes presented emerged from the first interviews done in 2005 and a subsequent literature review, via a classification of the concrete actions of CBRT support organizations. By "concrete actions" we mean what these organizations have done as opposed to what they should or would like to be doing. The discourse on what CBRT is or should be, such as an "advanced stage of ecotourism" [32], was not considered in the analysis. The theoretical perspective was developed and modified after an initial set of interviews, such that interviews carried out later in 2006 and 2007 had incorporated this theory into the following questions:

- With respect to CBRT, which are your contacts outside your organization?

- Which [NGOs, public institutions, international organizations, community organizations, tourism intermediaries] does your organization have contact with?

- How frequent has the communication been with each of these contacts?

- What did you [give, receive] from each of these contacts?

- Has your organization [given out, received] [cash donations, materials, loans, training]? [From whom, to whom]?

- Has your organization [participated in, organized] tourism fairs? 
- Has any organization controlled the quality standards of your organization? Which are these organizations?

- Has your organization controlled the quality standards of other organizations related to CBRT? Which are these organizations?

- Has your organization [participated in/conducted] meetings related to CBRT? Who participated in these meetings?

\section{RESEARCH FINDINGS}

The following sections report on the aspects that characterize the relationship between both ACTUAR and COOPRENA and their respective member GROs. As was reported in the preceding sections, these organizations have different organizational backgrounds, but nonetheless work in a similar way and coordinate their support for CBRT.

\section{Tackling High Development Costs}

Development costs refer to the components of the initial investment that must be done in order to start a business. GROs that belong to COOPRENA and ACTUAR have received direct economic support from several organizations, generally to supply specific material needs. For example, a representative of Stibrawpa (2006) mentioned having received donations in the form of infrastructure, boats, solar panels, cell phones, furniture and linen. The first major donor to CBRT projects was the SGP. From early 1995 to June 2005 , a total of 47 GROs had received support for tourism projects [37, 38].

In the practice of CBRT, loans are not as common as donations. However, there were some references in the interviews to representatives of GROs: A representative of COOPEUVITA (2006) mentioned that they had "a strategic alliance with a savings and loan cooperative, where they can loan an amount equal to the value of one of our [COOPEUVITA's] properties". A representative of COOPEUVITA mentioned receiving a loan from an NGO called the Costa Rica-Canada Foundation. Finally, a representative of COOPESILENCIO (2006) mentioned receiving a loan from a Costa Rican State-owned bank.

Some loans may also be granted by GRSOs. For example, ACTUAR used the following system for improving tourism infrastructure: Firstly, a representative visited the tourism project and collected information on which aspects needed to be improved. Then, ACTUAR informed the GRO what they needed to improve and gave them materials (e.g., paint). When the problems had been corrected, ACTUAR organized promotion for the tourism project. ACTUAR then deducted the cost of the materials from the money that the visitors paid.

Tourism has been promoted as a development strategy that combines economic growth with environmental conservation [21]. Because of this, there are two main discourses for fund seeking: social development and environmental conservation. GROs receive assistance as a means to get started in a productive activity. However, if a GRO is not generating sales, this assistance failed to meet its objective.

Despite funding, some of the groups have failed because they start out with utopian ideas, but are not able to imple- ment these ideas into a productive activity. Although visitation has been increasing, many supported GROs have failed to develop a profitable business (see Cordero [35]). In general, the variable costs are being covered, but the point of equilibrium between revenue and costs (including fixed costs such as depreciation and maintenance of equipment and infrastructure) has not been reached, and the impact on employment is mostly temporary [37].

\section{Providing Essential Skills}

Training is required since the change from agriculture to service activities is difficult for rural people [45]. They lack the knowledge and experience to successfully develop tourism activities. Some training has been executed directly by COOPRENA and ACTUAR, but most of it has been done by other organizations that were contacted for the purpose of bringing training to GROs. For example, The National Technical Education Institution (Instituto Nacional de Aprendizaje, INA) has had a major role in training the GROs associated with COOPRENA and ACTUAR. At the beginning, the instructors were not familiar with community-based projects; but later on, the contents and methodologies were tailored to their needs. Some external instructors with experience in rural tourism were hired by INA specifically for this task [37]. Some training has been organized by different combinations of organizations, who share the costs as well as the merit. For example, in 2004, an activity called "Workshop/exchange of experiences: From tourism projects to CBRT businesses" was arranged for participants representing 22 GROs. The workshop lasted 4 days and was celebrated at the tourism section of INA in San José. It was jointly organized by the SGP, the British Embassy, ACTUAR and INA [46].

As can be seen in this last example, training has involved the traveling of GRO representatives to urban centers. On the other hand, technical assistance has involved visits to CBRT projects from staff members of support organizations, in order to solve problems specifically related to tourism. A GRO representative mentioned that "donors always reserve a part of the funds for technical assistance" (Representative, Albergue la Amistad, 2006).

In terms of providing essential skills, it has been a challenge to find instructors and methodologies tailored for rural people. There is a challenge in teaching entrepreneurship to rural people, but without getting them into urban schemes (e.g., heavy dependence on technology) [47]. Several interviews revealed that some of the training and technical assistance did not comply with the proposed objectives, either because the jargon was too technical or because it did not fit into the reality of rural inhabitants. In the words of a representative of ACTUAR (2005):

"Sometimes we give out technical assistance, but during the process we realize that it is not going to be useful at all [for rural people]. Trainers sometimes use concepts that are not comprehensible from the trainee's perspective. In my view, this means that these trainers are not good professionals. A good professional is someone that can explain a complicated subject, but in a simple way that everybody can understand". 


\section{Developing International Standards}

One of the first efforts to link the GROs supported by UNDP with the private business sector was a focal group with tour operators. During this activity, "the operators pointed out that, although the supply [i.e., the tourism business counterpart to the tourist's demand] was attractive, it was not yet ready for the marketplace". The main reason they stated were problems related to quality standards [37: p. 45].

In 2005, ICT diagnosed the situation of 35 CBRT projects, according to their official standards. Seventy-nine percent did not reach one star, which means that they did not have the "minimal requisites of cleanliness and comfort" [48]. COOPRENA and ACTUAR, together with INA, ICT and Rainforest Alliance, have been making coordinated efforts so that these standards can be met. However, presenting the required paperwork has been complicated, especially when it requires that rural GRO representatives travel repeatedly to urban areas.

"To date, most GROs are part of the informal economic sector" (Representative, ACTUAR, 2006). However, "ICT cannot further support the marketing of the CBRT sector in general if the businesses that form part of it are not formally registered by ICT" (Representative ICT, 2007). This is why in 2006 the SGP organized a workshop for the formalization of GROs. Formalization involves giving out official receipts, operating under a business license, and providing insurance for the tourists.

The Certification for Sustainable Tourism (CST) is an ICT program that evaluates environmental practices. Rainforest Alliance has made an effort in recent years to improve the environmental performance of CBRT projects. In contrast to its efforts in sustainable agriculture and wood, Rainforest Alliance does not certify tourism activities. Instead, it has pushed for the incorporation of ACTUAR's and COOPRENA's members into the CST program:

"At the present moment, we are working with Costa Rican tourism businesses so that they implement good practices for sustainable tourism. Later on, they could obtain the CST that is given out by ICT, if they want to" (Representative, Rainforest Alliance, 2006).

In the words of a representative of Albergue la Amistad (2006):

"Rainforest Alliance has been monitoring and evaluating our projects. They first perform a diagnosis, and we set out to improve our performance based on it. In six months time, they come back. Last time they returned was at the beginning of this year [2006], and they saw that we had made a considerable improvement. Because of this positive evaluation, they will be doing a follow-up project, which includes economic support, in order to formalize the business".

\footnotetext{
${ }^{1}$ ICT is the authorized organization in charge of rating the quality of tourism businesses, from 0 to 5 stars. The items evaluated are: recreation facilities, cleanliness, public areas, rooms, bath rooms, eating areas, service to guests, maintenance, architecture, and gardens [48]
}

\section{Marketing}

Both ACTUAR and COOPRENA have their own tour operators. According to informants from each of these organizations, they perform as a marketing 'arm' for their member's tourism supply. A tour operator is an intermediary in the tourism industry that designs, organizes, packages, markets and operates tours [49]. In 1997, Symbiosis Tours was created [35] as a tour operator that belongs to COOPRENA and its affiliates [34]:

"What we do is sell tourism packages and programs for different tours, both to national and international tourists. About 60 to 70 percent of our packages have CBRT businesses included in them. We have to work with other businesses, because there are geographical areas that do not have CBRT projects, such as Tortuguero [a popular tourism destination in the Caribbean coast of Costa Rica], where many tourists seek to travel. Therefore, we have to find other types of hotels. But we don't use hotels that we know are damaging the environment. We try to find the ones that are more in tune with our line of business. If we cannot find a community-based business, then we try to find one that is as close to it as possible" (Representative, COOPRENA, 2005).

In the words of a representative of ACTUAR (2007): "We are a tour operator specializing in CBRT, called $A C$ TUAR Rural Adventures". In 2005, a representative of ACTUAR claimed that "an average of 30 tourists a month is channeled through ACTUAR to member associations" [47: p. 100]. In 2007, this number had increased to "an average flow of 50 passengers a month" (Representative, ACTUAR, 2007).

Some of the sales efforts are carried out by GROs. For instance, tourists can contact them by phone. Their number may appear on a tourism guidebook, or be given to them by another tourist. Additionally, some of the sales can be done indirectly through ACTUAR and COOPRENA, or by another tour operator or travel agency. After deducting a percentage of the income from the tourist, they proceed to pay the GRO. Informants reported that each GRO has between 5 and 40 connections to different travel agencies or tour operators.

The first edition of the CBRT guidebook was crucial in the development of the sub-sector, since it included both ACTUAR and COOPRENA. Labeling their product as 'CBRT' went through a long process. Before this guidebook, some of the GROs called their activity 'ecotourism' or 'agroecotourism'. COOPRENA named their activity 'communitybased agro-ecotourism', but the term evolved as CBRT, since rural tourism was a more commonly-used term (representative, COOPRENA, personal communication).

Marketing efforts include taking representatives from tour operators and the press to CBRT projects, as well as organizing the participation in national and international tourism fairs (Representative, Rainforest Alliance, 2006). Another marketing effort done by the GRSOs are tourism fairs specific to the CBRT sub-sector. In 2001, there was an incipient tourism fair for the groups supported by UNDP, called "Community-Based Ecotourism Fair". The fair was 
not open to the public, nor was there a massive invitation to other organizations, since most of the projects were involved in the construction of basic infrastructure, or receiving incipient training [50]. From 2002 onward, there have been annual CBRT fairs organized by different combinations of organizations. The number of booths has seen a substantial growth over the years (See Table 3 ).

In addition, a series of travel guidebooks specific to the sub-sector have also been produced. The first edition of the CBRT guidebook was published in 2002 by UNDP and COOPRENA, with support from various sponsors [51]. In 2003, the second CBRT guidebook was edited by UNDP, presenting 46 GROs [33]. The third CBRT guidebook was published by ACTUAR in 2007, with 57 GRO tourism projects [52].

Rainforest Alliance has supported both ACTUAR and COOPRENA in their marketing efforts. In the words of a representative of Rainforest Alliance (2006):

"At the host-country level, what we do is strengthen the supply [i.e., the tourism businesses], through training and technical assistance. At the regional level, which means Latin America, we are the leaders in a certification network for sustainable tourism. Finally, at the international level, we do marketing efforts and communicate."

This strategy has been important, since low quality service and facilities and lack of international marketing are the two main reasons why CBRT projects fail to compete with private sector projects [6].

\section{Advocacy}

Advocacy means influencing change at a political level (Yanacopulos, 2005). Both ACTUAR and COOPRENA have adopted advocacy as one of their main objectives, primarily by lobbying [53]. Solano [34: p. 45, translated for this study] stated that one of the main challenges facing COOPRENA is "an increased political incidence related to promotion, capacity-building and certification of CommunityBased Rural Tourism". To a representative of ACTUAR (2005), advocacy efforts are important, since:

"National policies are directed towards giving incentives to companies making big investments. Not many policies are promoting tourism microenterprises in the country. This can be seen in a wide range of policies, from the Tourism Board to INA" (Representative, ACTUAR, 2005).

NGOs form coalitions in order to influence other actors, particularly governments and international financial institutions. Unlike a loosely-connected network, a coalition involves broader aims and greater member commitment [53]. In 2004, a national coalition called CBRT Alliance was created [54]. It was integrated by COOPRENA, ACTUAR and the National Peasant Table (Mesa Nacional Campesina, a local NGO), with support from ACEPESA and the SGP [37]. The purpose of this alliance was to place CBRT in the national political agenda, so that state agencies would support CBRT [47]. Both ACTUAR and COOPRENA have formed an alliance with other organizations, so that they can tackle public policy (e.g., environmental, tourism, agricultural and education policies). Examples of their advocacy efforts are discussed as follows.

The interviewees expressed that representatives of ACTUAR and COOPRENA have met regularly with employees of INA and ICT. These regular meetings stemmed from a seminar organized in May 2005 by the tourism section of INA, called "The role of public institutions and private organizations in the development of rural tourism: A new alternative". Participants included various public institutions (public universities, technical education institutions, as well as the Ministries of the Environment and Agriculture), COOPRENA, ACTUAR, UNDP and Cultourica (a tour operator specialized in CBRT). As a result of this seminar, a Commission on Rural Tourism was created, coordinated by INA, with the objective of maintaining regular communication between organizations related to rural tourism [30].

The CBRT Alliance has pushed for legislation that benefits the sub-sector. In 2003, a law project was presented at the Costa Rican Legislature, to "promote national and community-based tourism". Its main objective was to move national holidays occurring on a Monday, Tuesday, Wednesday or Thursday to the closest Friday [55]. In 2004, after the lobby of COOPRENA, ACTUAR, ACEPESA and UNDP, the Special Tourism Commission of the Legislature added an article that required ICT to promote CBRT supply for the long weekends [56]. However, in 2005 when the law finally was approved, the text said that ICT "may promote" the supply of CBRT [57].

Table 3. CBRT Fairs Held in Costa Rica

\begin{tabular}{|c|c|c|c|}
\hline Fair Number & Year & Organized by & Number of Booths \\
\hline \hline I & 2002 & COOPRENA, ICT & N.A. $^{\text {a }}$ \\
\hline II & 2003 & COOPRENA, SGP, ICT & 40 \\
\hline III & 2004 & ACTUAR, COOPRENA, SGP, ICT & 78 \\
\hline IV & 2005 & ACTUAR, COOPRENA, MNC, with support from ICT, UNDP and ACEPESA & 75 \\
\hline V & 2006 & CBRT Alliance & 80 \\
\hline
\end{tabular}

${ }^{\mathrm{a}}$ Not available.

${ }^{b}$ National Peasant Table (Mesa Nacional Campesina), an NGO based in Costa Rica

${ }^{c}$ This Alliance includes the same organizations that organized the IV CBRT Fair.

Source: Based on Guereña \& Calderón [37]. 
In 2007, an executive power decree signed by the President of Costa Rica and two of his ministers, declared CBRT an activity of "public interest". State agencies, with a special mention of ICT, were allowed to collaborate with the development of the sub-sector, and therefore to use their resources in this endeavor [58]. A representative of ACTUAR added:

"They still maintain it as a Government policy and not as a State policy. A State policy would involve a Law, but well, at least for these four years it is justifiable to the Government [to support CBRT]. Thanks to this, we will have more space for action when asking for support from State institutions" (Representative, ACTUAR, 2006).

Another example of an effort to influence public policies was an activity that has come to be known as the "Ambush of Ministers":

"The Alliance was formed as a space for political negotiation, and one of the actions with most impact was the socalled 'Ambush of Ministers', in which the main Government authorities related to tourism, environment, agriculture and labor were summoned" [37: p. 70, translated for this study].

The results of this meeting have not been successful, as one interviewee noted:

"There were many organizations in this meeting, and one of the things we wanted was for the Ministers to hear from the mouth of a person from a [rural] community what we were doing. The president of the IMAS [the Institute of Social Aid, Instituto Mixto de Ayuda Social] raised his hand and started saying: "how is it that these projects are being developed and IMAS doesn't know anything about it. We can support them, there are resources to support this activity'. At the end of the meeting, he encouraged us to send him a formal letter. We are still waiting for a response from him. He said that in front of all the Ministers, but after about a month and a half, he said: "what a pity! We ran out of funds!' However, that day he pleased everybody, and everybody applauded him, everybody was writing down what he was promising, but it all ended there" (Representative, $\mathrm{Al}$ bergue la Amistad, 2006).

Guereña and Calderón [37: p. 40] narrated a "strategic alliance" between the SGP, COOPRENA and ICT's Promotion Department for the coordination of the release of the CBRT Guidebook, the participation in tourism fairs, the support of ICT for the annual CBRT fair, and the inclusion of CBRT in ICT's newspaper advertising.

Despite the efforts of the organizations involved, there is still a lack of legislation and institutional backing to regulate the sub-sector. Although alliances with NGOs may provide skills, funds and political influence, it is difficult for community-based tourism to expand without coherent policies and legislation $[6,59]$.

\section{SUMMARY AND CONCLUSIONS}

A unique characteristic of the community-based rural tourism policy in Costa Rica is the existence of GRSOs that, while having a membership of a series of GROs, also act as tour operators. For this research, two of the most emblematic of these organizations were studied, ACTUAR and COOPRENA.

It was found that the membership to GRSOs directly tackles three of the common problems faced by rural inhabitants in the practice of tourism (see Table 1), namely, lack of essential skills, high development costs and the dominance of mass tourism operators. It also showed that support networks allow small rural organizations and enterprises to exert political influence at the national and international levels.

Although the supported GROs are receiving tourists and revenues, there is no evidence that support networks would solve the problem of low employment and income, which is typical of rural tourism. Therefore, there is also no evidence that network involvement can help GROs become viable businesses once international aid ceases to arrive. In terms of policy, the implications of these findings depend on the objectives of the policy-makers and managers. Salafsky [60] argues that it could still make sense to subsidize CBT projects if it has environmental or social benefits, as long as the variable costs of operation are covered. On the other hand, Kiss [61] states that funds could be better spent via direct payments to rural residents.

Costa Rican public institutions have traditionally favored mass tourism development, so the main drive for the development of CBRT has come from the nonprofit sector. This has given CBRT development flexibility, but also instability for the years to come. In order to further develop the sector, a more coherent public policy could help in this aspect. This policy would involve skills training and technical assistance, and more importantly, effective marketing for the subsector.

The present research has shown the importance of support networks in the development of CBRT in Costa Rica. Two aspects have been found vital for the survival of both GROs and GRSOs: First, adaptation to changes in funding sources; and second, collaboration between organizations. GRSOs perform as social "bridges" in the social networks related to CBRT, since they connect GROs with other parts of the social system in ways that would otherwise be unconnected, or do it in a more efficient manner.

In his basic theoretical model, Granovetter [40] assumes both strong and weak ties to be positive and symmetric. This has presented a major limitation to our research, since, as we have discussed earlier, past research has identified power relations and inequalities as factors that affect CBT development. Although we found several examples in the fieldwork that could be interpreted as power struggles, we were not able to capture or explain them from our theoretical perspective. Notwithstanding, we found Granovetter's network theory to be particularly useful in explaining the development of support networks. If support for CBRT would not have been organized as a network, we doubt if it could have accomplished the level of development that the subsector has reached.

\section{REFERENCES}

[1] Hjalager AM. Agricultural diversification into tourism: Evidence from a European Community development programme. Tourism Manage 1996; 17(2): 103-11. 
[2] Sharpley R. Rural tourism and the challenge of tourism diversification: The case of Cyprus. Tourism Manage 2002; 23(3): 233-44.

[3] MacDonald R, Jolliffe L. Cultural rural tourism: Evidence from Canada. Ann Tourism Res 2003; 30(2): 307-22.

[4] Briedenhann J, Wickens E. Rural tourism -- meeting the challenges of the new South Africa. Int J Tourism Res 2004; 6(3): 189-203.

[5] Campbell LM. Ecotourism in rural developing communities. Ann Tourism Res 1999; 26(3): 534-53.

[6] Honey M. Ecotourism and sustainable development: Who owns paradise? Washington, D.C. Island Press 1999.

[7] Scheyvens R. Ecotourism and the empowerment of local communities. Tourism Manage 1999; 20(2): 245-49.

[8] Mitchell RE, Reid DG. Community integration: Island tourism in Peru. Ann Tourism Res 2001; 28(1): 113-39.

[9] Jones S. Community-based ecotourism: The significance of social capital. Ann Tourism Res 2005; 32(2): 303-24.

[10] Ramsa-Yaman A, Mohd A. Community-based ecotourism: A new proposition for sustainable development and environmental conservation in Malaysia. J Appl Sci 2004; 4(4): 583-9.

[11] Kontogeorgopoulos N. Community-based ecotourism in Phuket and Ao Phangnga, Thailand: Partial victories and bittersweet remedies. J Sus Tourism 2005; 13(1): 4-23.

[12] Jamal TB, Getz D. Collaboration theory and community tourism planning. Ann Tourism Res 1995; 22(1): 186-204.

[13] Reed MG. Power relations and community-based tourism planning. Ann Tourism Res 1997; 24(3): 566-91.

[14] Mbaiwa JE. The socio-economic and environmental impacts of tourism development on the Okavango Delta, North-western Botswana. J Arid Environ 2003; 54(2): 447-67.

[15] Wearing S, McDonald M. The development of community-based tourism: Re-thinking the relationship between tour operators and development agents as intermediaries in rural and isolated area communities. J Sus Tourism 2002; 10(3): 191-206.

[16] Belsky JM. Misrepresenting communities: The politics of community-based rural ecotourism in Gales Point Manatee, Belize. Rural Sociol 1999; 64(4): 641-66.

[17] Scheyvens R. Exploring the tourism-poverty nexus. Curr Issues Tourism 2007; 10(2\&3): 231-54.

[18] Sharpley R. Sustainable rural tourism development: Ideal or idyll? In: Roberts L, Hall D, Eds. Rural tourism and recreation: Principles to practice. Wallingford, UK: CAB International 2001; pp. 57-8.

[19] Wunder S. Ecotourism and economic incentives: An empirical approach. Ecol Econ 2000; 32(3): 465-79.

[20] Weaver DB, Lawton LJ. Twenty years on: The state of contemporary ecotourism research. Tourism Manage 2007; 28(5): 1168-79.

[21] Duffy R. The potential and pitfalls of global environmental governance: The politics of transfrontier conservation areas in Southern Africa. Polit Geogr 2006; 25(1): 89-112.

[22] Roberts SM, Roberts JPJ, Fröhling O. NGOs and the globalization of managerialism: A research framework. World Dev 2005; 33(11): 1845-64.

[23] Henry L, Mohan G, Yanacopulos H. Networks as transnational agents of development. Third World Q 2004; 25(5): 839-55.

[24] Ross S, Wall G. Evaluating ecotourism: The case of North Silawesi, Indonesia. Tourism Manage 1999; 20(6): 673-82.

[25] Fisher J. Is the iron law of oligarchy rusting away in the Third World? World Dev 1994; 22(2): 129-43.

[26] Sturm M. The mixed experience of private sector involvement in biodiversity management in Costa Rica. In: O'Riordan T, StollKleemann S, Eds. Biodiversity, sustainability, and human communities: Protecting beyond the protected. Cambridge, U.K: Cambridge University Press 2002; pp. 243-59.

[27] Roberts JT, Thanos ND. Trouble in paradise: Globalization and environmental crises in Latin America. New York and London: Routledge 2003.

[28] Mowforth M, Munt I. Tourism and sustainability: Development and new tourism in the Third World. London and New York: Routledge 2003.

[29] Campbell LM. Conservation narratives in Costa Rica: Conflict and co-existence. Dev Change 2002; 33(1): 29-56.

[30] Solano CM, Campos M. INA apoya el turismo rural. Tecnia: Revista del Instituto Nacional de Aprendizaje de Costa Rica 2006; 19(7): 5-12.
[31] ICT. Plan nacional de turismo 2002-2012. San José, Costa Rica: Author, 2006.

[32] Guereña A. Turismo rural comunitario: Conciliando el desarrollo y la conservación. Costa Rica: SGP/GEF 2004.

[33] UNDP. The real Costa Rica: Your community-based tourism guide. San José, Costa Rica: UNDP 2003.

[34] Solano L. Experiencia ambiental de Costa Rica en el desarrollo y posicionamiento del ecoturismo. La Habana, Cuba: UNDP 2003.

[35] Cordero A. De lo bello natural a lo bello social: Sistematización de las experiencias de COOPRENA 1992-2001. San José, Costa Rica: COOPRENA 2002.

[36] ALRCR (Asamblea Legislativa de la República de Costa Rica). Ley de asociaciones cooperativas y creación del Instituto Nacional de Fomento Cooperativo. San José, Costa Rica: Author, 1982.

[37] Guereña A, Calderón G. Turismo rural comunitario en Costa Rica: La experiencia del Programa de Pequeñas Donaciones y sus grupos socios. San José, Costa Rica: UNDP 2005.

[38] Guereña A. Turismo rural comunitario: El mejor destino. Revista Parlamentaria de la Asamblea Legislativa de Costa Rica 2005; 13(2): 299-308.

[39] Granovetter M. The strength of weak ties: A network theory revisited. Sociol Theor 1983; 1: 201-33.

[40] Granovetter M. The strength of weak ties. Am J Sociol 1973; 78(6): 1360-80.

[41] Granovetter M. The impact of social structure on economic outcomes. J Econ Perspect 2005; 19(1): 33-50.

[42] Granovetter M. A theoretical agenda for economic sociology. In: Guillen M, Collins R, England P, Meyer M, Eds. The new economic sociology: Developments in an emerging field. New York: Russell Sage Foundation 2002; pp. 35-59.

[43] Berggren A, Elfving A. Communication structure and information distribution in an Indian NGO network. MSc [thesis]. Borås, Sweden: Swedish School of Library and Information Science, University College of Borås 2004.

[44] Rutten R. Inter-firm knowledge creation: A re-appreciation of embeddedness from a relational perspective. Eur Plan Stud 2004; 12(5): 659-73.

[45] Watanabe T. Final report on rural tourism in Costa Rica. San José, Costa Rica: JICA/INA 2005.

[46] SGP. Taller/intercambio de experiencias: De proyectos turísticos a empresas de turismo rural comunitario. San José, Costa Rica: UNDP 2004.

[47] Trejos B, Huang WC, Chiang LHN. Support networks for community-based rural tourism in Costa Rica. J Int Cooperation 2006; 1(1): 88-106.

[48] Guzmán J. Estudio de perfil: Caracterización de la oferta y la demanda de turismo rural comunitario. San José, Costa Rica: ICT/UNDP 2005.

[49] Weaver DB. The encyclopedia of ecotourism. Oxon, U.K: CAB International 2001.

[50] UNDP. Promoción y mercadeo de proyectos: Ecoturismo comunitario. Informe: feria de ecoturismo comunitario. San José, Costa Rica: UNDP 2001.

[51] UNDP/COOPRENA. Rural community tourism guide. San José, Costa Rica: UNDP/COOPRENA 2002.

[52] Cruz K, Solano L. Costa Rica auténtica: La guía de turismo rural. San José, Costa Rica: ACTUAR 2007.

[53] Yanacopulos H. The strategies that bind: NGO coalitions and their influence. Global Netw 2005; 5(1): 93-110.

[54] Merino L, Sol R. Elementos sobre la participación de la sociedad civil en la gestión ambiental. San José, Costa Rica: Programa Estado de la Nación 2005.

[55] ALRCR. Proyecto de ley: Ley para promover el turismo nacional y rural comunitario. San José, Costa Rica: Author, 2003.

[56] ALRCR. Ley para promover el turismo nacional y rural comunitario: Expediente N ${ }^{\circ}$ 15501. San José, Costa Rica: Author, 2004.

[57] ALRCR. Reforma del segundo párrafo del artículo 148 del Código de Trabajo, Ley $\mathrm{n}^{\circ} 2$, y sus reformas, para promover el turismo nacional. San José, Costa Rica: Author, 2005.

[58] Poder Ejecutivo de la República de Costa Rica (PERCR). Decreto $\mathrm{N}^{\circ}$ 33536-MP-TUR. La Gaceta 2007; 129(17): 9.

[59] Akama JS. Western environmental values and nature-based tourism in Kenya. Tourism Manage 1996; 17(8): 567-74. 
[60] Salafsky N, Cauley H, Balachander G, Cordes B, Parks J, Margoluis C, Bhatt S, Encarnación C, Russell D, Margoluis R. A systematic test of an enterprise strategy for community-based biodiversity conservation. Conserv Biol 2001; 15(6): 1585-95.
[61] Kiss A. Is community-based ecotourism a good use of biodiversity conservation funds? Trends Ecol Evol 2004; 19(5): 232-37.

(C) Trejos et al.; Licensee Bentham Open.

This is an open access article licensed under the terms of the Creative Commons Attribution Non-Commercial License (http://creativecommons.org/licenses/ by-nc/3.0/) which permits unrestricted, non-commercial use, distribution and reproduction in any medium, provided the work is properly cited. 